\title{
Opinions of High School Nursing Students on Integrating Medical IT Applications in Vocational Classes in Sisak-Moslavina County
}

1 Jelena Lučan

${ }^{1}$ Viktorovac High School, Sisak, Croatia

Article received: 11.06.2019.

Article accepted: 11.09.2019.

DOI: $10.24141 / 2 / 3 / 2 / 2$

Author for correspondence:

Jelena Lučan

Viktorovac High School

Aleja narodnih heroja 1, Sisak

E-mail: jjokic1@gmail.com

Keywords: documentation, primary health care, students

\section{Abstract}

Aim. To examine whether high school nursing students have a positive opinion on using medical IT applications in classes of vocational subjects Nurse in Primary Healthcare and Principles of Administration and whether students' opinions regarding integrating medical IT applications in classes were related to their knowledge on nursing documentation and attitudes towards its use in primary healthcare.

Methods. The study was conducted in the form of a cross-sectional study. In total, there were 84 participants, all students of the Viktorovac High School in Sisak, who filled in a questionnaire consisting of 37 questions. The answers were defined by the Likert rating scale.

Results. Sixty-six (79\%) students completely agree with the claim that using the application prior to the workplace is useful. 59 (70\%) completely agree that being well-trained in using the application ensures a higher quality documenting skills. 40 (48\%) students ranked their knowhow in test application as very good (knowhow sufficient for serious work with the application in primary healthcare), and 21 (25\%) as excellent. Those students who ranked their knowhow as higher significantly less agree with the claim that there is no need to document nurses' work and activities.

Conclusion. High school nursing students hold positive opinions towards integrating medical IT applications in vocational subjects' classes. Students' opin- 
ions towards integrating medical IT applications in classes are related to their knowledge on nursing documentation and attitudes towards its use in primary healthcare.

\section{Introduction}

Primary level of health care is available to all residents of the Republic of Croatia. Primary health care includes a family doctor, a pediatrician, a gynecologist and a doctor of dental medicine. Other levels of health care are generally used by patients when referred by their primary care physician. As a rule, a primary health care doctor usually has a long-term contact with the patient who is registered with him/ her, so he/she is able to collect numerous data about the patient, his/her family, illnesses, use of all other services in the healthcare system, prescribed medicines, his/her own work, and the like. It is well known that the amount and quality of patient data collected is associated with better quality of patient care and rational use of available health facilities (1). The primary care team includes a doctor of medicine and a nurse. The team is obliged to send daily reports of their work and monthly submit all forms and reports in electronic form through the Central Health Information System of the Republic of Croatia (CEZIH) to the Croatian Health Insurance Fund (HZZO). Modern information technologies bring changes to the existing way of work of all health professionals, who must acquire new knowledge, but also participate with their own proposals in the development of medical IT applications themselves.

The scope of nurses' work has changed due to the advancement of information and communication technology (ICT). Based on the Nursing Act, nurses always had to prepare relevant patient care documentation. This process has been digitalized by the progress of ICT. The biggest wave of informatization occurred in primary health care, and the work of the nurse in the outpatient clinic is to a large extent related to the administrative part. Nurses employed in primary care infirmaries are in charge of administrative tasks (patient enrollment through the application, checking the patient's health insurance, issuing bills) and performing diagnostic-therapeutic procedures prescribed by the doctor. Nurses will send electronic messages through $\mathrm{CEZIH}$ regarding the payment of the participation fee for supplemental insurance or issue a payment slip to the patient if the patient has no insurance or is not exempt from payment under certain conditions (e.g.children, disabled persons). Medical and administrative information are classified information and doctors and nurses have a professional responsibility to keep all patient information secure (2).

Students must learn to properly keep administrative and medical records of the patient prior to going to training. Considering that it is impossible for students to immediately work on real data, as this would mean impermissible possibility of error on the real patient data, incorrectly entered vital signs, incorrectly recorded division of therapy, etc., the leading Croatian manufacturer of health information systems has given a free trial version of the program (Medicus.Net) to Viktorovac High School in Sisak. Documenting nursing work in primary health care is a legal obligation and a professional responsibility, it provides legal protection, ensures quality communication among team members, improves quality of health care, provides a complete set of data on patient needs and goals of nursing care, contains chronological overview of care and results achieved, enables research and better cost control. The need to make some basic information about the computer and practical skills of its use became part of general education as early as primary school (in some ways even in kindergarten), as well as the first attempts, successes and difficulties, are explained by the new term - "computer literacy"(3). In our country, the teaching of Informatics in health schools was introduced in 1990, in the first grade with 35 school hours per year, and in the second grade with 70 school hours per year. Croatian Nursing Council (CNC) was established in 2003, and that same year, with the adoption of the Nursing Act (Official Gazette 121/2003), keeping nursing records became compulsory (4). In July 2006, CNC issued recommendations for keeping nursing records.

The student must adopt the content prescribed by the curriculum and the teacher must ensure an effective teaching process. One of the key competencies of future workers is computer literacy. More recently, technology (e.g. smart boards) has been increasingly used in teaching, which also affects the teach- 
ing process itself. It is the teacher's role to properly combine and use all media. The advantage of the elearning system is its accessibility to all users, which involves the use of various communication channels. E-learning systems in use today most commonly use the Internet as a medium for communication with the user (5). ICT enables rapid exchange of information between teachers and students. Since the software application used by the students in the teaching process is part of the fifth generation of computer programs, i.e. mentor programs - it has highly differentiated expertise and logical data management processes, greatly facilitated the work of the user, but also requires education so that the student can make the most of its possibilities. In order for the students to practice administrative work before going to work sites (primary health care infirmaries), access to the application is provided on the computers in the IT classroom and the school library. Five school hours before going to training at the infirmaries, students practice data entry using the test application. The test version of the application is identical to the user version (the one the staff actually work on at the infirmary). Considering it is a web-based application, installation was not required, the application is accessed on a computer, through the Internet connection, a server address, and with a user code and password. Students could also access the application from home, from a computer, tablet or smartphone. In order to ensure proper work of the application, it is best to access it through Google Chrome. Information about the link, user, and password for logging in to the application, as well as instructions for working in the primary healthcare application except for the teaching exercises, were also forwarded to the students by a joint e-mail. Application Access Link: https://demo.medicusnet.hr/MedicusLogin/Test/

Depending on the primary health care activity, instructions for using the Medicus.Net program are as follows:

- General practice: http://public.mcs.hr/upute/MCS/Upute-OpcaBrziUnos.pdf

- Pediatrics: http://public.mcs.hr/upute/MCS/Upute-Pedijatrija.pdf

- Gynecology: http://public.mcs.hr/upute/MCS/Upute-Ginekologija.pdf
One of the basic parameters that has changed our educational system, as well as all aspects of human life, has been the Internet explosion, more specifically the Web, as a medium of instructional delivery. The appeal of learning using ICT is undeniable. It can overcome distance and reduce costs; it is available at any time, in accordance with student needs. Online educational materials can be updated more easily than traditional textbooks, and communication channels between teachers and students are always open (6). Today's educational goals are significantly different from those set in the last century. Instead of focusing on the complete transformation of education and new challenges that society requires, we seek to adapt the outdated education system by shifting problems from one area to another. The rational solution is to educate students to know how to learn in a constantly changing society. Transformation of the education model requires adopting a studentcentered curriculum that makes students proficient in collaboration, finding, analyzing, organizing, evaluating, and adopting new information in accordance with their own needs and academic and cultural background (6).

Like any other learning, e-learning is a process consisting of four key elements, namely the teacher, the teaching content, technology and the learner. In e-learning, the emphasis is on a particular type of educational technology in which computer mediates teaching content between the teacher and the student and vice versa, and which is of particular importance in this respect, which is sometimes referred to as the didactic quadrilateral of e-learning. The most common and purely technical definition of e-learning is that of Fallon and Brown (2003): "E-learning is any form of learning, teaching or education that is aided by the use of computer technologies, and in particular computer networks based on Internet technologies" (7). In their classrooms teachers and students daily create a singular aura that depends on a unique spatial, temporal and social context. Online-supported education is always accompanied by the elimination of student-teacher interaction here and now, that is, the loss of aura. In the age of online technical reproduction, one should not be afraid of downplaying the role of the teacher: the aura of education is unique and can only be created by man. On the other hand, the internet definitely provides a level of access to information that no creature can otherwise reach. In order to get the best out of the machine and 
the human, the tasks we put before them need to be balanced so that both do the work that suit them best (8).

Given that at the Viktorovac High School, the work on the test application was introduced for the subject Nurse in Primary Health Care, students come more ready for teaching exercises at the infirmaries, they independently (under the supervision of mentors and nurses) enter the data, and work in the real user programme. It is also interesting that during the exercise the students noticed some "shortcomings" of the application, such as the inability to record all nursing procedures. Therefore, it can be said that the students participated in the testing of the application, and thus their creativity and innovative thinking came to the fore. The application of ICT promotes the development of motivation, social skills, cooperation, and a sense of community (9).

The students successfully use the application, they are interested and often self-initiate entering data in the application, stating that all documents (prescriptions, referrals, aids, medical transport, sick leave, etc.) seemed rather vague until they started using the application themselves. Nurses in primary care infirmaries also play an advisory role. In the advisory role, nurses plan, implement, and record patient health care $(10,11)$.

Students can enter patient measurement values into the application, such as weight and height, and the application automatically calculates body mass index. Based on the measured values, the student knows what advice needs to be given to the patient, such as diet, exercise, avoiding salt and fat for high blood pressure and high body mass index. Additionally, when entering blood pressure values, the application automatically creates a chart and connects the diastolic and systolic blood pressure values with previous measurements.

Prior to the computerization of primary health care, each document (prescription, referral, orthopedic aids, medical transport, travel warrant, etc.) had to be completed "manually", which greatly delayed and complicated the work. Today, with a single mouse click, all chronic patient prescriptions are sent to the pharmacy via CEZIH, and with a single click, records of all diagnostic (laboratory and specialist findings) are obtained, which truly saves both time and paper. Also, all patient files are in electronic form (EHR), no longer needed to be stored in paper form, which saves office space. Since 2008, family medicine physicians have had to keep an electronic health record on one of the Ministry of Health and Welfare's approved programmatic solutions. There are various manufacturers of IT applications, however, the principle of working in all applications is similar, and when a student masters working in one application, he/she can easily understand and use another. The list of certified manufacturers by all areas can be checked on the HZZO website: http://www.cezih.hr/ certificirani_proizvodjaci_aplikacija.html.

Among the certified manufacturers is Medicus.Net, the MCS Grupa d.o.o. application provided at the school, since Sisak Health Center uses this application in all areas. Adequate training in the application allows students to focus more on the patient during the teaching exercises. Students are often given tasks to be done in the test version of the application. It is sufficient to access the application and see quickly and easily which student has done which of the tasks for the given patient, which makes it easy to track the student's achievements.

Until the in-app data entry skills are brought to the level of automaticity, students look for the icon that they must select instead of communicating with the patient. In order to acquire the skill of using the program, students practice working with the application in the IT classroom before going to practice in the infirmary, and are also given homework. The IT classroom and library of Viktorovac High School are well equipped, so no additional investment was needed. Computers set up for work in the application are always available in the school library. Each participant also needs their own technology: hardware, network and software.

The student needs a computer and a network connection to access the educational material. In addition to the basic PC operating system, the student also needs add-ons such as a web browser and a multimedia viewer. The system, that is, the server, consists of a network server and a software package. In addition, it requires a high-speed network connection to deliver information to many students who are simultaneously accessing it (12). High-speed Internet connection must be provided to access the application, and if a problem with the Internet occurs the application cannot be used until the malfunction is corrected. 


\section{Aim}

The aim of this study is to examine the opinions of the nursing students of Viktorovac High School on the use of the medical IT application in teaching the subjects Nurse in Primary Health Care, and Principles of Administration. It also seeks to examine whether students' opinions on integrating a medical IT application in teaching are related to their knowledge of nursing records, and attitudes towards its application in primary care.

\section{Hypotheses}

Hypothesis 1. Nursing high school students have a positive opinion towards integrating the medical IT application in the teaching of the subjects Nursing in Primary Health Care and Principles of Administration.

Hypothesis 2. Nursing high school students' opinions towards integrating a medical IT application in teaching are related to their knowledge of nursing documentation and attitudes towards its application in primary care.

\section{Methods}

\section{Participants}

The inquiry was conducted on a total of 84 students of the Viktorovac High School in Sisak in the period from July 1 to July 72018 .

Of the total 84 students, $55(65.5 \%)$ are 4 th grade students and 45 (35.5\%) are 5th grade students. By gender, there are slightly more young women, 57 (68\%) than young men (Table 1 ).

\section{Table 1. Respondents' characteristics}

\begin{tabular}{|cc|}
\hline Sex & Number (\%) of students \\
\hline Female students & $57(68)$ \\
\hline Male students & $27(32)$ \\
\hline Grade & Number (\%) of students \\
\hline 4th grade & $55(66)$ \\
\hline 5th grade & $29(34)$ \\
\hline Total & $\mathbf{8 4}(\mathbf{1 0 0 )}$ \\
\hline
\end{tabular}

All students were fully trained to work in a web-based medical-informatics technology application (Medicus. Net) for primary health care. The training was carried out as a part of teaching exercises in the subject Nursing in Primary Health Care on the computers in the computer room and library of the Viktorovac High School, and through the tasks in the subject Principles of Administration that students had to finish prior to attending the teaching exercises in primary healthcare infirmaries.

\section{Instrument}

The survey was conducted using a questionnaire consisting of thirty-seven questions. The first part of the questionnaire covers general data on respondents' characteristics, gender, and year of education. The second part of the questionnaire examines the students' opinions on the use of the medical IT application in the teaching of the subjects Nursing in Primary Health Care, and Principles of Administration. In four questions, students choose one of the answers offered, and in the statements (16 statements) that follow, they circle the figure that best reflects their opinion using the Likert scale (1 - strongly disagree, 2 - disagree, 3 - not sure, 4 - agree, 5 - totally agree). This examines their opinion on how well they have mastered the possibilities of the medical IT application and whether they can adequately apply the acquired knowledge in working on teaching exercises in primary health care infirmaries. The third part of the questionnaire examines students' opinions about the usefulness/significance of learning and working in a primary health care test application. In four statements, students circle the figure that best reflects their opinion using the Likert scale (1- completely disagree, 2 - disagree, 3 - not sure, 4 - agree, 5 - strongly agree). This examines whether the knowledge of using the patient's electronic health record and knowing how to work in an application in primary health care can help students in the educational process, or while working with patients in teaching exercises. The fourth part of the questionnaire examines students' opinions on nursing documentation in the Primary Health Care (PHC). In a total of twelve statements, students circle the figure that best reflects their opinion using the Likert scale ( 1 - strongly disagree, 2 - disagree, 3 - not sure, 4 - agree, 5 - strongly agree). This examines the students' opinions about what nursing documentation in primary health care entails and why it is important to keep nursing documentation in primary health care. 


\section{Statistics}

Categorical data are represented by absolute and relative frequencies. Differences of categorical variables were tested by the Fisher's exact test. Numerical data are described by the median and the limits of the interquartile range. The normality of the distribution of numerical variables was tested by the Shapiro-Wilk test, and in the results which showed deviations from the normal distribution for all variables, non-parametric methods were used. Differences in numerical variables between the two independent groups, 4th and 5th grade students, and gender differences were tested with the Mann-Whitney $U$ test. The correlation between normally distributed numerical variables was evaluated by Spearman's correlation coefficient $\rho$ (rho). All $\rho$ values are twosided. The significance level was set to Alpha $=0.05$. The statistical software MedCalc Statistical Software version 18.2.1 (MedCalc Software bvba, Ostend, Belgium; http://www.medcalc.org; 2018) and SPSS (IBM Corp. Released 2013. IBM SPSS Statistics for WindowsVersion 21.0. Armonk, NY: IBM Corp.) were used for statistical analysis.

\section{Results}

$40(48 \%)$ students rated their knowledge and skill in using the test application as very good (knowledge and skills quite sufficient to work seriously with the PHC application), while 4 (5\%) said that they had sufficient knowledge (scarce knowledge and skills, barely sufficient to work with the application in the PHC). Since this is a web application, 58 (69\%) students access the application from a PC or laptop. When given homework to create a simulation of patient processing in the primary health care team, 47 (56\%) students did the task independently, without difficulty. There are no significant differences in the assessment of one's own knowledge and skills in the use of the application, the manner and frequency of access to the application by gender.

$66(79 \%)$ students fully agree with the statement that in-app training before going to work sites (primary care infirmaries) is useful, and 57 (68\%) with the statement that they generally find learning through test applications useful. 59 (70\%) students fully agree that adequate training in using the application ensures higher quality of documentation. $47(56 \%)$ students agree with the statement that the benefits of working in a medical IT application is to understand how to implement what they have learned during class and 49 (58\%) students agree that adequate training in using the application ensures greater accessibility of patient information.

When compared to $4^{\text {th }}$ grade students, $5^{\text {th }}$ grade students are significantly more likely to use instructions (written or video instructions) when working with the test application (Mann-Whitney $\mathrm{U}$ test, $p=0.01$ ) and agree with the statement that the advantage of working in the application is understanding how to implement what they have learned during class (Mann-Whitney U test, $p=0.04$ ) (Table 3).

$57(68 \%)$ students fully agree that the knowledge of using the application and electronic health record data in primary health care contributes to improving

\begin{tabular}{|c|c|c|c|c|}
\hline & \multicolumn{3}{|c|}{ Number (\%) of students } & \multirow[t]{2}{*}{$\mathbf{p}^{*}$} \\
\hline & $\begin{array}{c}\text { Female } \\
\text { students }\end{array}$ & $\begin{array}{c}\text { Male } \\
\text { students }\end{array}$ & Total & \\
\hline \multicolumn{5}{|c|}{ Assess your own knowledge and skills of using the test application } \\
\hline $\begin{array}{l}\text { Sufficient (scarce knowledge and skills, barely sufficient to work } \\
\text { with PHC application) }\end{array}$ & $2(4)$ & $2(7)$ & $4(5)$ & \multirow{4}{*}{0.73} \\
\hline Good (basic knowledge and basic skills of using PHC application) & $14(25)$ & $5(19)$ & $19(23)$ & \\
\hline $\begin{array}{l}\text { Very good (knowledge and skills quite sufficient to work seriously } \\
\qquad \text { with the application in the PHC) }\end{array}$ & $28(49)$ & $12(44)$ & $40(48)$ & \\
\hline Great (excellent knowledge and use of the PHC application) & $13(23)$ & $8(30)$ & $21(25)$ & \\
\hline
\end{tabular}




\section{Table 3. Assessment of their own knowledge and skills of using the application, the manner and} frequency of access to the application in relation to the class attending

\begin{tabular}{|c|c|c|c|c|}
\hline & (int & $\begin{array}{l}\text { Median } \\
\text { quartile ran }\end{array}$ & & $p^{*}$ \\
\hline & 4th grade & 5 th grade & Total & \\
\hline $\begin{array}{c}\text { Didactic knowledge acquired in test medical IT application can } \\
\text { be adequately applied to working in the real application in } \\
\text { teaching exercises. }\end{array}$ & $5(4-5)$ & $4(4-5)$ & $4(4-5)$ & 0.13 \\
\hline $\begin{array}{l}\text { I find that I have fully understood the capabilities of the test } \\
\text { application. }\end{array}$ & $4(3-5)$ & $4(3-4)$ & $4(3-5)$ & 0.65 \\
\hline $\begin{array}{l}\text { I find that I have completely mastered working in the } \\
\text { application. }\end{array}$ & $4(3-5)$ & $4(3-4)$ & $4(3-4)$ & 0.40 \\
\hline $\begin{array}{l}\text { Using a test application seems easy enough and } \\
\text { understandable to students. }\end{array}$ & $4(3-5)$ & $4(3-5)$ & $4(3-5)$ & 0.74 \\
\hline $\begin{array}{c}\text { The test application should be further refined and adapted to } \\
\text { students. }\end{array}$ & $3(3-4)$ & $4(3-4)$ & $4(3-4)$ & 0.47 \\
\hline $\begin{array}{l}\text { When practising in the IT classroom the teaching content on the } \\
\text { test application was understandable to me. }\end{array}$ & $4(4-5)$ & $4(4-5)$ & $4(4-5)$ & 0.68 \\
\hline $\begin{array}{l}\text { Practicing in-app before going to the job site (primary care } \\
\text { infirmaries) seems helpful. }\end{array}$ & $5(5-5)$ & $5(4.5-5)$ & $5(5-5)$ & 0.63 \\
\hline I find learning through test applications useful. & $5(4-5)$ & $5(4-5)$ & $5(4-5)$ & 0.24 \\
\hline I find learning through test applications interesting. & $5(4-5)$ & $5(4-5)$ & $5(4-5)$ & 0.93 \\
\hline $\begin{array}{l}\text { When doing the practice tasks I used instructions (written or } \\
\text { video instructions) to work in the test application. }\end{array}$ & $3(2-4)$ & $4(4-5)$ & $4(3-4)$ & 0.01 \\
\hline $\begin{array}{l}\text { Adequate training in using the application allows me to have } \\
\text { more time for professional jobs regarding the patient during } \\
\text { teaching exercises. }\end{array}$ & $5(4-5)$ & $5(4-5)$ & $5(4-5)$ & 0.97 \\
\hline $\begin{array}{l}\text { Computerization of nursing data offers an opportunity to } \\
\text { improve nursing care. }\end{array}$ & $5(4-5)$ & $5(4-5)$ & $5(4-5)$ & 0.16 \\
\hline $\begin{array}{l}\text { Adequate training in using the application ensures greater } \\
\text { accessibility of patient information. }\end{array}$ & $5(4-5)$ & $5(4-5)$ & $5(4-5)$ & 0.39 \\
\hline $\begin{array}{l}\text { Adequate training in using the application ensures greater } \\
\text { quality of documentation. }\end{array}$ & $5(4-5)$ & $5(5-5)$ & $5(4-5)$ & 0.21 \\
\hline $\begin{array}{l}\text { Adequate training in using the application makes it less likely to } \\
\text { make mistakes in teaching exercises. }\end{array}$ & $5(4-5)$ & $5(4-5)$ & $5(4-5)$ & 0.07 \\
\hline $\begin{array}{c}\text { The benefits of working in a medical-informatics application } \\
\text { for students is to understand how to implement what we have } \\
\text { learned during class. }\end{array}$ & $4(4-5)$ & $5(4-5)$ & $5(4-5)$ & 0.04 \\
\hline Mann-Whitney U test & & & & \\
\hline
\end{tabular}

education, and $53(63 \%)$ agree with the statement that this knowledge makes it easier for them to do the teaching exercises in a doctor's office.

There are no significant differences in the evaluation of the use of the application and electronic health records in $\mathrm{PHC}$ by gender or grade.
$58(69 \%)$ students fully agree that the use of the application facilitates communication among team members (doctor - nurse - home care nurse), while 23 $(27 \%)$ are uncertain whether it needs to be adapted to the nurses further (Table 4).

There is no significant difference by gender in the assessment of what nursing documentation in primary health care implies. 


\section{Table 4. Assessment of what nursing documentation in primary care entails}

\begin{tabular}{|c|c|c|c|c|c|}
\hline \multirow{2}{*}{$\begin{array}{c}\text { Nursing documentation in PHC entails } \\
\ldots\end{array}$} & \multicolumn{5}{|c|}{ Number (\%) of students } \\
\hline & $\begin{array}{l}\text { I fully } \\
\text { disagree }\end{array}$ & I disagree & $\begin{array}{l}\text { I'm not } \\
\text { sure }\end{array}$ & I agree & I fully agree \\
\hline $\begin{array}{l}\text { The link between identifying health care } \\
\text { needs, planning, delivering, and evaluating } \\
\text { provided health care }\end{array}$ & 0 & $2(2)$ & $4(5)$ & $25(30)$ & $53(63)$ \\
\hline Ensuring continuity of patient care & 0 & $1(1)$ & $4(5)$ & $25(30)$ & $54(64)$ \\
\hline Providing data for nursing research & 0 & $1(1)$ & $4(5)$ & 31 (37) & $48(57)$ \\
\hline $\begin{array}{l}\text { Facilitating communication among team } \\
\text { members (doctor - nurse - home care nurse) }\end{array}$ & $1(1)$ & 0 & $2(2)$ & $23(27)$ & $58(69)$ \\
\hline $\begin{array}{l}\text { No managing required while mostly } \\
\text { recorded by the doctor }\end{array}$ & $21(25)$ & $31(37)$ & $17(20)$ & $9(11)$ & $6(7)$ \\
\hline Needs to be further adjusted to nurses & $2(2)$ & $7(8)$ & $23(27)$ & 31 (37) & $21(25)$ \\
\hline
\end{tabular}

$4^{\text {th }}$ grade students agree significantly more with the statement that nursing documentation in the PHC entails the link between identifying health care needs, planning, delivering, and evaluating provided health care (Mann-Whitney U test, $p=0.02$ ), and that it needs to be further adjusted to nurses (MannWhitney $U$ test, $p=0.008$ ) (Table 5).

Most students, 57 (68\%), agree with the statement that it is important to keep nursing records in order to improve the quality of health care, and for 56 (67\%) students the importance of keeping nursing records lies in the need to ensure better communication, whereas 55 (65\%) see its advantage in legal protection (Table 6).

Female students agree significantly more with the statement that keeping nursing records in PHC is important because of legal obligations, compared to young men (Mann-Whitney $U$ test, $p=0.002$ ) (Table 7).

$5^{\text {th }}$ grade students agree significantly more with the statement that keeping nursing records in PHC is important for determining professional responsibility, compared to $4^{\text {th }}$ grade students (Mann Whitney $U$ test, $p=0.002$ ) (Table 8 ).

When asked what they would change while learning through test applications, most students would not change anything, while 19 (23\%) students would introduce more hands-on work with their teacher before going to a real work site (PHC infirmaries), with no significant difference by gender of the student (Table 9).

Significantly more $5^{\text {th }}$ grade students would not change anything while learning through test applica-

\section{Table 5. Assessment of what nursing documentation in the PHC entails by the student's grade}

Median

Nursing documentation in PHC entails ...

The link between identifying health care needs, planning, delivering, and evaluating provided health care.

Ensuring continuity of patient care

Providing data for nursing research

Facilitating communication among team members (doctor nurse - home care nurse)

No managing required while mostly recorded by the doctor Needs to be further adjusted to nurses (interquartile range)

$4^{\text {th }}$ grade $\quad 5^{\text {th }}$ grade $\quad$ Total

$\begin{array}{cccc}4(4-5) & 5(5-5) & 5(4-5) & \mathbf{0 . 0 2} \\ 5(4-5) & 5(4-5) & 5(4-5) & 0.37 \\ 5(4-5) & 5(4-5) & 5(4-5) & 0.32 \\ 5(4-5) & 5(4.5-5) & 5(4-5) & 0.28 \\ 2(1-3) & 2(1.5-4) & 2(1.3-3) & 0.31 \\ 3.5(3-4) & 4(3.5-5) & 4(3-4.8) & \mathbf{0 . 0 0 8}\end{array}$




\section{Table 6. Assessment of the importance of keeping nursing records in PHC}

\begin{tabular}{|c|c|c|c|c|c|}
\hline & \multicolumn{5}{|c|}{ Number (\%) of students } \\
\hline & $\begin{array}{l}\text { I fully } \\
\text { disagree }\end{array}$ & I disagree & $\begin{array}{l}\text { I'm not } \\
\text { sure }\end{array}$ & I agree & I fully agree \\
\hline Determining professional responsibility & 0 & $1(1)$ & $3(4)$ & $27(32)$ & $53(63)$ \\
\hline Legal obligations & 0 & $1(1)$ & $9(11)$ & $25(30)$ & $49(58)$ \\
\hline Ensuring better communication & 0 & 0 & $3(4)$ & $25(30)$ & $56(67)$ \\
\hline Legal protection & 0 & $1(1)$ & $2(2)$ & $26(31)$ & $55(65)$ \\
\hline Improving quality of health care & $1(1)$ & $1(1)$ & $5(6)$ & $20(24)$ & $57(68)$ \\
\hline $\begin{array}{l}\text { No need to document nursing work in } \\
\text { primary health care }\end{array}$ & $48(57)$ & $10(12)$ & $7(8)$ & $10(12)$ & $9(11)$ \\
\hline
\end{tabular}

\section{Table 7. Assessment of the importance of keeping nursing records in PHC by gender}

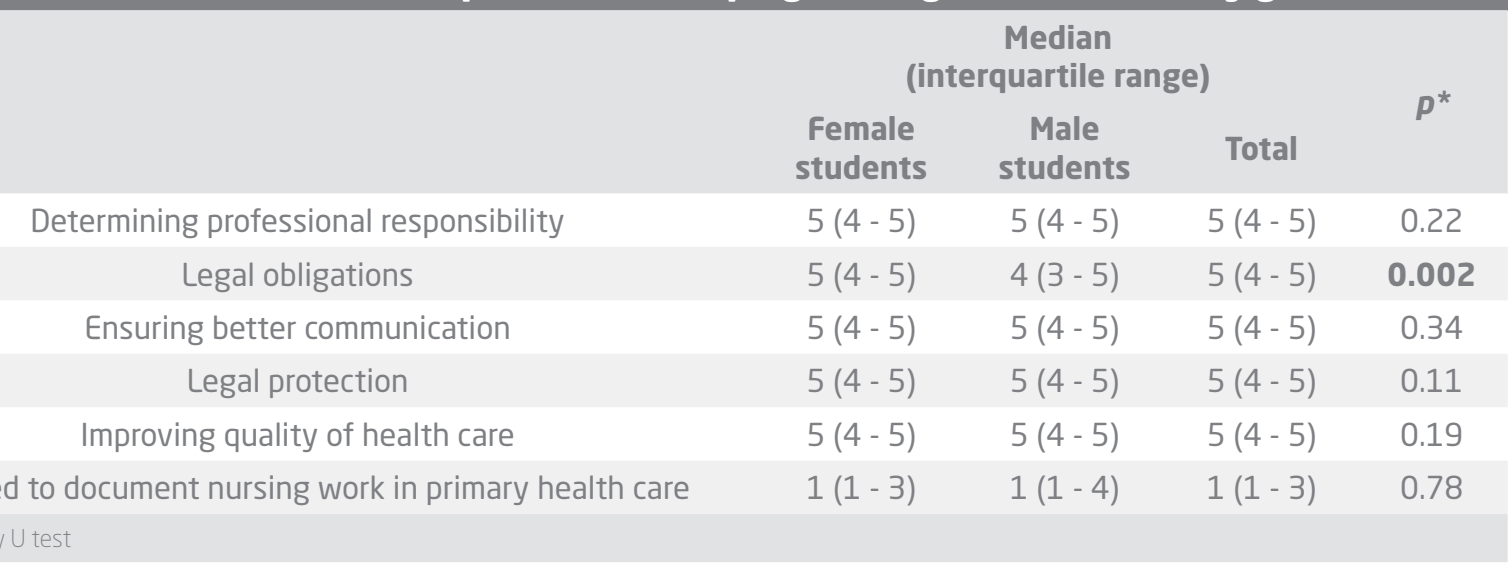

\section{Table 8. Assessment of the importance of keeping nursing records in PHC by the grade}

\section{Median}

(interquartile range)

$\begin{array}{lcccc} & \mathbf{4}^{\text {th }} \text { grade } & \mathbf{5}^{\text {th }} \text { grade } & \text { Total } & \\ \text { Determining professional responsibility } & 4(4-5) & 5(5-5) & 5(4-5) & \mathbf{0 . 0 0 6} \\ \text { Legal obligations } & 5(4-5) & 5(4-5) & 5(4-5) & 0.75 \\ \text { Ensuring better communication } & 5(4-5) & 5(4.5-5) & 5(4-5) & 0.16 \\ \quad \text { Legal protection } & 5(4-5) & 5(4-5) & 5(4-5) & 0.53 \\ \text { Improving quality of health care } & 5(4-5) & 5(4.5-5) & 5(4-5) & 0.23 \\ \text { to document nursing work in primary health care } & 1(1-3) & 1(1-4) & 1(1-3) & 0.44 \\ \text { U test } & & & & \end{array}$

tions, while $4^{\text {th }}$ grade students would introduce significantly more hands-on work with the teacher before going to a real work site, or working in the teaching process on a test application for hospital information system (Fisher's exact test, $p<0.001$ ) (Table 10).

Spearman's correlation coefficient assesses the correlation between the rating of one's own knowledge and the skills of using the test application with the opinion and attitudes about the application. Students who rated their knowledge higher agree significantly more with the statement that didactic knowledge learned in test medical IT application can be adequately applied to working in the real application in teaching exercises and that they have fully understood the capabilities of 


\section{Table 9. What would you change while learning through test applications by gender}

\begin{tabular}{|c|c|c|c|c|}
\hline \multirow{2}{*}{$\begin{array}{l}\text { What would you change while learning through test } \\
\text { applications }\end{array}$} & \multicolumn{3}{|c|}{ Number $(\%)$ of students } & \multirow[t]{2}{*}{$p^{*}$} \\
\hline & $\begin{array}{l}\text { Female } \\
\text { students }\end{array}$ & $\begin{array}{l}\text { Male } \\
\text { students }\end{array}$ & Total & \\
\hline I wouldn't change anything & $28(49)$ & $15(56)$ & $43(51)$ & \multirow{7}{*}{0.85} \\
\hline I find it very useful in practice & $2(4)$ & $1(4)$ & $3(4)$ & \\
\hline Make it more accessible to students & $1(2)$ & $1(4)$ & $2(2)$ & \\
\hline I would put more tasks (homework) & $2(4)$ & $2(7)$ & $4(5)$ & \\
\hline $\begin{array}{l}\text { More practical work with the teacher before going to a real } \\
\text { work site (PHC infirmaries) }\end{array}$ & $14(25)$ & 5 (19) & $19(23)$ & \\
\hline $\begin{array}{l}\text { Introduce work in the teaching process on test application } \\
\text { for the hospital information system }\end{array}$ & $10(17.5)$ & $3(11.1)$ & $13(15.5)$ & \\
\hline Total & $57(100)$ & $27(100)$ & $84(100)$ & \\
\hline
\end{tabular}

*Mann-Whitney U test

\begin{tabular}{|c|c|c|c|c|}
\hline \multirow{2}{*}{$\begin{array}{l}\text { What would you change while learning through test } \\
\text { applications }\end{array}$} & \multicolumn{3}{|c|}{ Number (\%) of students } & \multirow[t]{2}{*}{ p* } \\
\hline & $\begin{array}{l}\text { Female } \\
\text { students }\end{array}$ & $\begin{array}{l}\text { Male } \\
\text { students }\end{array}$ & Total & \\
\hline I wouldn't change anything & $24(44)$ & $19(66)$ & $43(51)$ & \multirow{7}{*}{$<0.001$} \\
\hline I find it very useful in practice & 0 & $3(10)$ & $3(4)$ & \\
\hline Make it more accessible to students & $1(2)$ & $1(3)$ & $2(2)$ & \\
\hline I would put more tasks (homework) & $1(2)$ & $3(10)$ & $4(5)$ & \\
\hline $\begin{array}{l}\text { More practical work with the teacher before going to a real } \\
\text { work site (PHC infirmaries) }\end{array}$ & $16(29)$ & $3(10)$ & $19(23)$ & \\
\hline $\begin{array}{l}\text { Introduce work in the teaching process on test application } \\
\text { for the hospital information system }\end{array}$ & $13(23.6)$ & 0 & $13(15.5)$ & \\
\hline Total & $55(100)$ & $29(100)$ & $84(100)$ & \\
\hline
\end{tabular}

the test application. Additionally, they feel that they have completely mastered working in the application. Practicing in-app work prior to going to work sites (primary health care infirmaries) is useful to them, as well as learning through test applications in general, and adequate training in using the application, according to the respondents, makes it less likely to make mistakes in teaching exercises. Knowledge of using the application and patients' electronic health record data in primary health care will help them find employment and compete in the job market more easily. The students who rated their knowledge and skills higher significantly less agree with the statement that there is no need to document nursing work in primary health care (Table 11).

\section{Discussion}

With the development of information and communication technology, information literacy is becoming one of the professional competencies of the nurse. An information literate person knows how to use information for a specific purpose (19). Primary care nurse uses the medical IT application to record all necessary administrative and medical data about the patient. $40(48 \%)$ students rated their knowledge and skill in using the test application as very good (knowledge and skills sufficient to work seriously with the application in the $\mathrm{PHC}$ ), and 21 (25\%) rated 


\section{Table 11. Significant correlation of assessment of own knowledge and skills of using the test application with the opinion and attitudes about nursing documentation in PHC}

\begin{tabular}{|c|c|c|}
\hline & \multicolumn{2}{|c|}{$\begin{array}{l}\text { Spearman's correlation coefficient of the } \\
\text { rating of one's own knowledge and skills } \\
\text { in using the test application }\end{array}$} \\
\hline & $\rho$ (Rho) & p value \\
\hline $\begin{array}{c}\text { Didactic knowledge learned in test medical IT application can be } \\
\text { adequately applied to working in the real application in teaching } \\
\text { exercises. }\end{array}$ & 0.405 & $<0.001$ \\
\hline I find that I have fully understood the capabilities of the test application. & 0.415 & $<0.001$ \\
\hline I find that I have completely mastered working in the application. & 0.480 & $<0.001$ \\
\hline $\begin{array}{l}\text { Practicing in-app before going to the job site (primary care infirmaries) } \\
\text { seems helpful. }\end{array}$ & 0.292 & 0.007 \\
\hline I find learning through test applications useful. & 0.295 & 0.007 \\
\hline $\begin{array}{l}\text { Adequate training in using the application makes it less likely to make } \\
\text { mistakes in teaching exercises. }\end{array}$ & 0.230 & 0.04 \\
\hline $\begin{array}{l}\text { Knowledge of using the application and patients' electronic health } \\
\text { record data in primary health care will help me find employment and } \\
\text { compete in the job market easier }\end{array}$ & 0.231 & 0.04 \\
\hline No need to document nursing work in primary health care & -0.355 & 0.001 \\
\hline
\end{tabular}

it excellent. Based on the results obtained, we can expect the students to be able to use the application for work in the primary health care infirmaries very well after finishing school.

Since this is a web application, 58 (69\%) students mostly access the application from a PC or laptop, and when given homework to create a simulation of patient processing in the primary care team, 47 (56\%) students did the task independently, without the help of teachers or written/video instructions. Through their regular education, the students of Viktorovac High School in Sisak acquire computer knowledge and skills through subjects such as Informatics, Principles of Administration and Nursing in Primary Health Care, and information and communication technology is a part of their everyday lives. Informatics as a subject in secondary education of nurses comprises 35 school hours of lectures in the first grade and 70 school hours of exercises in the second grade, while the Principles of Administration comprises 37 school hours of teaching and the subject Nurses in Primary Health Care 37 school hours of lectures and 74 school hours of exercises (14). It can be assumed that frequent use of various IT applications results in more developed skills of using the application itself. 29 (35\%) students are not sure whether the test application should be refined and adapted to students.
Nurses also state that they are not fully satisfied with the electronic nursing records because they do not meet the needs for adequate records of daily practice (15). Medical IT application are not fully customized for nurses. No primary health care software solution contains a part where a nurse can keep his/her own nursing records, which has been recognized by students. The reason for this response lies in the fact that it is not possible to record nursing diagnoses or health care plans, which should be possible to write if the nurse has the possibility to record nursing work with the patient in diagnostic and therapeutic procedures (DTP). Some examples of records of DTP procedures for general medicine are 0M022 - telephone consultation with a nurse, $0 M 032$ - first visit of a nurse at home, OM033 - a control visit of a nurse at home that can be recorded through the application (16). Although there is a possibility to record DTP, there is no possibility of a more extensive record of procedures performed by the nurse and further nursing documentation.

Advisory work also comes to light when designing various "panels". The nurse takes certain patient information (e.g. height, weight, blood glucose values, blood pressure values, waist circumference, hip range, physical activity, smoking, alcohol, narcotics, drugs) and enters it into some of the offered "panels" and measurements. When recording this data, the 
nurse could also create a health care plan, but the application does not have the possibility to enter it.

With the introduction of EHRs and general computerization of the health system, nurses in primary health care have in some ways become an "invisible" part of the health system. Nurses in PHC do not have their documentation and cannot record the quantity and quality of work performed or services provided. At the same time, by increasing the availability and range of community health services, there is a need to increase the number of educated nurses, to increase professional competencies, and thus the need for additional knowledge and skills (17). The fact is that applications need to be more tailored to nurses. The students were right to notice that there is no way to record all the procedures they carry out in teaching exercises in primary care infirmaries.

66 (79\%) students fully agree with the statement that practicing in-app work before going to work sites (primary care infirmaries) is useful, and 57 (68\%) students find learning through test applications generally useful. If we compare this data with the data of the research by Rafaj G., who examined the problem of recording nursing work in primary health care, and conducted the research with the employees of the Bjelovar-Bilogora County Health Center who use the same application as Viktorovac High School (Medicus. Net, MCS grupa d.o.o.), a lack of IT education is evident. Only seven out of 98 respondents completed some of the IT courses, and nine had received basic training before working on a computer in the workplace (17). From the above, we can conclude that there is a benefit of working in the application before going to job sites, because if students are familiar with the application when they enter the job market, the employer will not have to invest in further education of their future employees.

59 (70\%) students fully agree that adequate training in using the application ensures higher quality of documentation, and 49 (58\%) students agree with the statement that adequate training in using the application ensures greater accessibility of patient information. A 2014 study by Rafaj G., which examines the attitude of nurses, users of the application, yields the most positive results for the statement that computers provide greater data accessibility, and respondents also believe that computers provide higher quality of documentation (17). It is evident that students have also recognized the usefulness and purpose of learning to work in a test application for PHC.
There are no significant differences in the assessment of one's own knowledge and skills in the use of the application, the manner and frequency of access to the application by gender. On the other hand, $5^{\text {th }}$ grade students agree significantly more than $4^{\text {th }}$ grade students with the statement that they use the instructions (written or video instructions) to work in a test application when doing the practice tasks. This information should be further researched and its cause examined. It is possible that the younger generations use various applications more easily, and that by updating the application itself, it has become more user friendly. The manufacturer, as it were, regularly updates the application not only according to $\mathrm{HZZO}$ regulations, but also at the request of the user, thus adapting it to the user.

57 (68\%) students fully agree that the knowledge of using the application and electronic health record data in primary health care contribute to improving education, and $53(63 \%)$ agree with the statement that this knowledge makes it easier for them to do the teaching exercises in a doctor's office. A study by Lee and associates finds that health professionals with computer science knowledge completed computer tasks faster and easier and had a more positive attitude towards computerization (18).

$58(69 \%)$ students fully agree that the use of the application facilitates communication among team members (doctor - nurse - home care nurse). The results of Rafaj G. in 2014 are almost identical, according to which $68.4 \%$ of the respondents agree that using the application facilitates communication among team members (17). In the application, the nurse has the ability to enter the reason for the patient's arrival to the doctor, as well as the values of vital signs. All these measurements can be entered by the nurse before the patient is examined by a doctor. Physicians and nurses have clearly defined complementary and reciprocal roles, and would use shared documentation that would allow for a continuous flow of information aimed at patient well-being and enhance mutual trust and respect (19).

$4^{\text {th }}$ grade students significantly more agree with the statement that nursing documentation in the PHC entails the link between identifying health care needs, planning, delivering, and evaluating provided health care, and that it needs to be further adjusted to nurses. It is possible that the differences between 4th and 5th grade students are due to the fact that 4 th grade students are attending the subjects Nurs- 
ing in Primary Health Care and Administration Principles, so their knowledge of the application itself and its benefits is more recent.

Most students, 57 (68\%), agree with the statement that it is important to keep nursing records in order to improve the quality of health care, whereas 55 $(65 \%)$ see its advantage in legal protection. The results obtained by Rafaj $G$. in survey of nurses' attitudes is similar, where respondents agree that nursing records ensure continuity of care $(70.4 \%)$, while $74.5 \%$ believe that nursing records should be kept for legal protection (17). The imperative of nursing is the collection, interpretation, and storage of data into nursing records, which by further processing provides information that forms the basis for quality improvement and health care development $(19,20)$. Graves Farrell, as the nurses' legal adviser, states that nurses have often recorded all procedures concerning patients for fear of losing their jobs. If there is no documentation, there is no evidence (21).

Young women agree significantly more with the statement that keeping nursing records in $\mathrm{PHC}$ is important because of legal obligations, compared to young men. It has also been observed that young men find it easier to cope with in-app work as well as computer work, and often offer to enter administration data in the infirmary on their own, while young women are more likely to observe the work and question what to do in the event of a mistake. There is a need to further investigate why gender differences exist.

$5^{\text {th }}$ grade students agree significantly more with the statement that keeping nursing records in $\mathrm{PHC}$ is important for determining professional responsibility, compared to $4^{\text {th }}$ grade students. The final grade students are more mature, their schooling is coming to an end, and they will soon find themselves in the role of a nurse. They have also heard about professional responsibility through attending other subjects, and additionally in the final year there are more teaching exercises and they have been faced to a greater extent with the problem of professional responsibility.

When asked what they would change while learning through test applications, most students would not change anything, while 19 (23\%) students would introduce more hands-on work with their teacher before going to a real work site (PHC infirmaries). Before going to the clinical practice in primary health care infirmaries, students spend 5 school hours in the IT classroom. This is an indication that classroom exercises with the teacher could be held over a number of school hours so that students would arrive to the infirmaries fully prepared.

Significantly more $5^{\text {th }}$ grade students would not change anything while learning to use test applications, while $4^{\text {th }}$ grade students would introduce significantly more hands-on work with the teacher before going to a real work site, and working in the teaching process on a test application for hospital information system. This answer points to the creative thinking of the students as we are currently expecting a test version of the hospital information system that we would also implement in class. Perhaps this is more important for $4^{\text {th }}$ grade students because they are still in the process of schooling, while $5^{\text {th }}$ grade students are at the end of their education.

Students who rated their knowledge higher agree significantly more with the statements: didactic knowledge learned in test medical IT application can be adequately applied to working in the real application in teaching exercises; they have fully understood the capabilities of the test application; they feel that they have completely mastered working in the application; practicing in-app work prior to going to work sites (primary health care infirmaries) is useful to them; learning through test applications is useful in general, and adequate training in using the application makes it less likely to make mistakes in teaching exercises, and knowledge of using the application and patients electronic health record data in primary health care will help them find employment and compete in the job market easier. The students who rated their knowledge and skills higher significantly less agree with the statement that there is no need to document nursing work in primary health care.

A survey conducted by Ljubičić in 2009 indicates that users have a more positive view of using nursing documentation through CEZIH if they have greater IT skills. Respondents claim that IT literacy is paramount in improving the quality of nursing record keeping. Nurses also state that keeping nursing records is mandatory and also serves as a legal document in the event of an incident (22). It is extremely important that nurses have recognized their important role in creating medical IT applications, offering solutions and suggesting application manufacturers in order to facilitate keeping nursing records (23). The same can be said for nursing high school students. 


\section{Conclusions}

Based on the conducted research and the results obtained, the following conclusions can be drawn:

- students find learning through test applications useful, and that adequate training in using the application ensures greater quality of documentation

- self-assessment of knowledge and skills of the test application shows that half of the students rate the knowledge and skills in the application with a very good grade (knowledge and skills sufficient for serious work with the application in the $\mathrm{PHC}$ )

- students agree with the statement that the benefits of working in a medical IT application are understanding how to implement what they have learned during class and that adequate training in using the application ensures greater accessibility of patient information

- most students fully agree that the knowledge of using the application and electronic health record data in primary health care contribute to improving education, as well as with the statement that this knowledge makes it easier for them to do the teaching exercises in a doctor's office

- most students fully agree that the use of the application facilitates communication among team members (doctor - nurse - home care nurse), while some of them are uncertain whether it needs to be adapted to the nurses further

- most students agree with the statement that it is important to keep nursing records in order to improve the quality of health care, next is ensuring better communication, and finally for legal protection

- most students would not change anything when learning through test applications, while some students would like more hands-on work with the teacher before going to a real work site ( $\mathrm{PHC}$ infirmaries)

There are some gender differences:

- female students agree significantly more with the statement that keeping nursing records in $\mathrm{PHC}$ is important because of legal obligations, compared to male students.
There are some differences with regard to the student's grade:

- 5th grade students agree significantly more than 4th grade students with the statement that they use the instructions while doing the practice tasks

- 4th grade students agree significantly more with the statement that nursing documentation in the PHC entails the link between identifying health care needs, planning, delivering, and evaluating provided health care

- significantly more 5th grade students would not change anything while learning through test applications, while 4th grade students would introduce significantly more hands-on work with the teacher before going to a real work site, and working in the teaching process on a test application for hospital information system.

Hypothesis 1 is confirmed. Medical school students have a positive opinion of the integration of the medical IT application in the teaching of professional subjects Nursing in Primary Health Care and Principles of Administration.

Hypothesis 2 is confirmed. Students' opinions about integrating the medical IT application into teaching are related to their knowledge of nursing documentation and attitudes about its application in primary health care. 


\section{References}

1. Kern J, Petrovečki M. Medicinska informatika. Zagreb: Medicinska naklada; 2009. Croatian.

2. Ericsson Nikola Tesla d.d. Informacijski sustav primarne zdravstvene zaštite Republike Hrvatske. Poslovni proces. Zagreb, 26.09.2005. Available from: http:// www.cezih.hr/pzz/dokumenti_pzz/HR_PHCIS_BusinessProcess.pdf Accessed: 28.08.2018. Croatian.

3. Mužić V, Rodek S. Kompjutor u preobražaju škole. Zagreb: Školska knjiga; 1987. Croatian.

4. Narodne novine. Službeni list Republike Hrvatske. Zakon o sestrinstvu. NN 121/2003; 1710. Available from: https://narodne-novine.nn.hr/clanci/sluzbeni/2003_07_121_1710.html Accessed: 01.09.2018. Croatian.

5. Fagerberg T, Rekkedal T. Enhancing the flexibility of distance education - designing and trying out a learning environment for mobile distance learners. 21st World Conference on Open \& Distance Education, Life long Learning in the Networked World. Hong Kong, 2004.

6. Banek Zorica M. E - učenje temeljeno na objektima učenja. Lasić - Lazić J, urednik. Informacijska tehnologija u obrazovanju, znanstvena monografija. Zagreb: Zavod za informacijske studije; 2014. Croatian.

7. Afrić V. Tehnologije e- obrazovanja i njihov društveni utjecaj. Lasić - Lazić J, urednik. Informacijska tehnologija u obrazovanju, znanstvena monografija. Zagreb: Zavod za informacijske studije; 2014. Croatian.

8. Jandrić P. Digitalno učenje. Zagreb: Tehničko veleučilište u Zagrebu; 2014. Croatian.

9. Abou Aldan D, Kralj Z. Četvrti stručni skup Društva nastavnika zdravstvene njege i Drugi stručni skup Društva za povijest sestrinstva [Koprivnica 22.03.2016]. Sestrinski glasnik. 2016;21(3):213-5. Croatian.

10. Fruk Marinković M. Kontinuirana odgovornost za profesionalnost i informacijsku pismenost medicinskih sestara. Acta Med Croatica. 2014;68:33-6. Croatian.

11. Kičić M. E-zdravlje - savjetodavna uloga medicinske sestre. Acta Med Croatica. 2014;68:65-9. Croatian.
12. CEZIH. Popis certificiranih proizvođača programske podrške po djelatnostima. Available from:

http://www.cezih.hr/certificirani_proizvodjaci_aplikacija.html Accessed: 27.08.2018. Croatian.

13. Cheevakasemsook A, Chapman Y, Francis K, Davies C. The study of nursing documentation complexities. Int J Nurs Pract. 2006;12(6):366-74.

14. Ministarstvo znanosti, obrazovanja i sporta. Strukovni kurikulum za stjecanje kvalifikacije: Medicinska sestra opće njege/ medicinski tehničar opće njege. Zagreb, 2011. Available from: https://www.asoo.hr/UserDocsImages/8.11.2013/kurikulum/Medicinska\%20 sestra\%20op\%C4\%87e\%20njege-medicinski\%20 tehni\%C4\%8Dar\%20op\%C4\%87e\%20njege.pdf Accessed: 30.08.2018. Croatian.

15. Kelley TF, Brandon DH, Docherty SL. Electronic nursing documentation as a strategy to imrove quality of patient care. J Nurs Scholarsh. 2011;43(2):154-62.

16. HZZO. Šifrarnici HZZO -a: DTP postupci u PZZ. Verzija 04.07.2018. Available from: http://www.hzzo.hr/hzzoza-partnere/sifrarnici-hzzo-a/ Accessed: 30.08.2018.

17. Rafaj G. Problem evidentiranja sestrinskog rada u primarnoj zdravstvenoj zaštiti [diplomski rad]. Zagreb: Medicinski fakultet Sveučilišta u Zagrebu; 2014. Croatian.

18. Lee TT, Lee TY, Lin KC, Chang PC. Factors affecting the use of nursing information systems in Taiwan. J Adv Nurs. 2005;50:1708.

19. Kalauz S. Etika u sestrinstvu. Zagreb: Medicinska naklada; 2012. Croatian.

20. Čukljek S. Teorija i organizacija u zdravstvenoj njezi nastavni tekstovi. Zagreb: Zdravstveno veleučilište u Zagrebu; 2008. Croatian.

21. Ferrell KG. Documentation, part 2: The best evidence of care. Complete and accurate charting can be crucial to exonerating nurses in civil lawsuits. Am J Nurs. 2007;107(7):61-4.

22. Ljubičić M. Implementacija sestrinske dokumentacije u informacijski zdravstveni sustav i utjecaj na kvalitetu zdravstvene njege [diplomski rad]. Zagreb: Zdravstveno veleučilište u Zagrebu; 2010. Croatian.

23. Kern J. Informacijske i komunikacijske tehnologije u sestrinstvu. Acta Med Croatica. 2014;68(1):3-5. Croatian. 


\section{MIŠLJENJA UČENIKA MEDICINSKE ŠKOLE O INTEGRIRANJU MEDICINSKO-INFORMATIČKIH APLIKACIJA U NASTAVI STRUČNIH PREDMETA U SISAČKO-MOSLAVAČKOJ ŽUPANIJI}

\section{Sažetak}

Cilj. Cilj je ovoga rada ispitati mišljenje učenika Srednje škole Viktorovac u Sisku o primjeni medicinskoinformatičke aplikacije u nastavi stručnih predmeta Medicinska sestra u primarnoj zdravstvenoj zaštiti i Načela administracije te jesu li mišljenja učenika o integriranju medicinsko-informatičke aplikacije u nastavi povezana $s$ njihovim znanjem o sestrinskoj dokumentaciji i stavovima prema njezinoj primjeni u primarnoj zdravstvenoj zaštiti.

Metode. Istraživanje je provedeno kao presječna studija. Ukupno je sudjelovalo 84 učenika Srednje škole Viktorovac u Sisku s pomoću anketnog upitnika koji se sastoji od 37 pitanja. Odgovori se definiraju primjenom Likertove skale procjena.

Rezultati. Šezdeset i šest (79 \%) učenika u potpunosti se slaže $s$ tvrdnjom da je vježbanje rada u aplikaciji prije odlaska na radilišta korisno. Da dobra uvježbanost primjene aplikacije osigurava veću kvalitetu dokumentiranja u potpunosti se slaže 59 (70 \%) učenika. Svoje znanje i vještinu uporabe testne aplikacije 40 (48 \%) učenika ocijenilo je ocjenom vrlo dobar (znanja i vještine sasvim dostatne za ozbiljan rad s aplikacijom u PZZ-u), a izvrsnom ocjenom ocijenio se 21 (25 \%) učenik. Oni učenici koji su svoje znanje i vještine ocijenili višom ocjenom znatno se manje slažu s tvrdnjom da ne postoji potreba za dokumentiranjem sestrinskog rada.

Zaključak. Učenici Srednje škole Viktorovac u Sisku imaju pozitivno mišljenje o integriranju medicinsko- informatičke aplikacije u nastavi stručnih predmeta. Mišljenja učenika o integriranju medicinsko-informatičke aplikacije u nastavi povezana su s njihovim znanjem o sestrinskoj dokumentaciji i mišljenjima o njezinoj primjeni u primarnoj zdravstvenoj zaštiti.

Ključne riječi: dokumentacija, primarna zdravstvena zaštita, učenici 